\title{
Effects of pulse and press additions of salt on biofilms of nutrient-rich streams
}

\author{
Joaquín Cochero ${ }^{\mathrm{a}, \mathrm{b}, *}$, Magdalena Licursi ${ }^{\mathrm{a}, \mathrm{b}, \mathrm{c}}$, Nora Gómez ${ }^{\mathrm{a}, \mathrm{b}}$ \\ a Instituto de Limnología “Dr. Raúl A. Ringuelet”, Facultad de Ciencias Naturales y Museo, Universidad Nacional de La Plata, 1900 La Plata, Argentina \\ b CONICET, Consejo Nacional de Investigaciones Científicas y Tecnológicas, Argentina

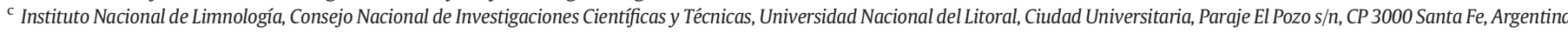

\section{H I G H L I G H T S}

- Biofilms from eutrophic streams were exposed to pulse and press increments in salinity.

- The experiment was conducted in microcosm for $72 \mathrm{~h}$, with a 72 hs recovery period.

- Bacterial abundance and oxygen consumption decreased due to both treatments.

- The proportion of abnormal nuclei in diatoms increased due to the chronic exposure.

- All effects reverted to control levels after $72 \mathrm{~h}$ of recovery

\section{GR A P H I C A L A B S T R A C T}

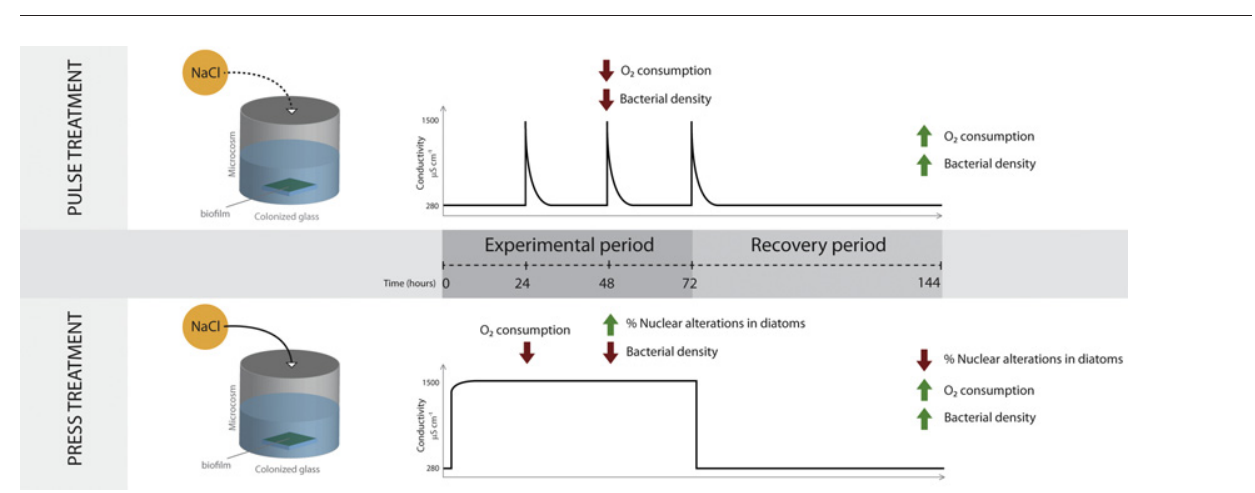

\section{A R T I C L E I N F O}

\section{Article history:}

Received 5 October 2016

Received in revised form 21 November 2016

Accepted 21 November 2016

Available online 1 December 2016

Editor: D. Barcelo

\section{Keywords:}

Salinization

Epipelic biofilm

Microcosm

Community recovery

Short-term experiment

\begin{abstract}
A B S T R A C T
Chronic and pulse increments of salinity can cause different consequences on the aquatic communities, and its effects are related to factors such as the magnitude, frequency and ionic composition, as well as on the baseline salt concentrations in the water. The aim of this study was to explore the responses of the biofilms from a nutrient-rich stream to both pulse and chronic additions of salt, along with their recovery after the stressor had been removed. For this purpose, a microcosm study was conducted exposing biofilms to water enriched with sodium chloride in two treatments ( press and pulse), and comparing the changes in the biofilm with control microcosms without salt additions. The experiment lasted $72 \mathrm{~h}$, and the variables measured included bacterial density, chlorophyll- $a$ concentration, community composition, total carbohydrate content, oxygen consumption and the percentage of nuclear alterations in diatoms. Both treatments resulted in a decrease in the bacterial density of the biofilm and in oxygen consumption; the chronic treatment in particular also caused an increased percentage of nuclear abnormalities in the diatom assemblage. The biofilm recovered to control levels after the treatments had been discontinued for $72 \mathrm{~h}$. We concluded that the biofilms can be altered significantly under both chronic and pulse additions of salt even after a short-term exposure, and that the community can recover if the stressor is withdrawn.
\end{abstract}

(c) 2016 Elsevier B.V. All rights reserved.

\footnotetext{
* Corresponding author at: Instituto de Limnología "Dr. Raúl A. Ringuelet”, Facultad de Ciencias Naturales y Museo, Universidad Nacional de La Plata, 1900 La Plata, Argentina.

E-mail address: jcochero@ilpla.edu.ar (J. Cochero).
}

\section{Introduction}

Salinization can have many origins and its effects on the biota of rivers and streams have been the subject of multiple studies, particularly in 
the last decades (such as Davis et al., 2003; Cañedo-Argüelles et al., 2013, 2014, 2016). In the Pampean plains of Argentina, this process is related to the intensive groundwater exploitation for crop harvesting, which has produced depression cones in the subterranean water level leading to the encroachment of the brackish water from the Río de la Plata estuary. Thus, the original groundwater flows from the plain to the estuary are being modified, giving origin to a saltwater intrusion into the surface waters that cause a continuous disturbance in their hydrochemical characteristics (Kruse et al., 2005). Additionally, water pumped for irrigation in this area carries dissolved salts that are not fully absorbed by the vegetation, which may be leached out through run-off in pulses, and end up in the rivers and streams during rainfall events (Kruse et al., 2005). These rivers and streams are naturally described by having high concentrations of nutrients and sodium chloride type waters (Carol and Kruse, 2012; Giorgi et al., 2005; Feijoó and Lombardo, 2007), and the disturbances caused to the aquatic communities by this salinization process is poorly studied.

The effects of salinization on the biota can depend on factors such as the magnitude, frequency and ionic composition, as well as on the baseline salt concentrations in the water (Pilkaitytë et al., 2004; Nielsen et al., 2003; Gutiérrez-Cánovas et al., 2012; Cañedo-Argüelles et al., 2014). The input of salt can also interact with the nutrient cycles in the stream (Baldwin et al., 2006; Lovett et al., 2007), making it difficult to separate the effects of salinization from those caused by nutrient enrichment. It is therefore likely that the responses of the microbial community developed in a nutrient-rich environment differ from those responses of biofilms developed in oligotrophic streams.

On freshwater biofilms, high salt concentrations have been reported to have effects on the composition of both the algal and the bacterial communities (Wunsam et al., 2002; Abed et al., 2007; Zhang et al., 2014). More specifically in the diatom assemblage, salinization can reduce their density (Busse et al., 1999) and even alter their external cell morphology (Trobajo et al., 2011), but its consequences on their intracellular-components (i.e. abnormalities in the nucleus or chloroplasts) has not been widely studied. The chlorophyll- $a$ concentration in biofilm, as a measure of total algal biomass, is also affected by salinity, and intermediate magnitudes enhance the development of the algal biomass with negative effects at higher salinity levels (Silva et al., 2000). The primary production and oxygen consumption follow this pattern, and both have been shown to rise when exposed to low salinity increments, but to decline when exposed to high salinity increments (Silva and Davies, 1999; Silva et al., 2000; Herbst and Blinn, 1998). The release of extracellular polymeric substances by algae and bacteria, such as polysaccharides and other carbohydrates (Hoagland et al., 1993; Ivorra et al., 2000) have also been shown to increase in relation to salinity increments, acting as a buffer to cells and their processes (Decho, 2000; Steele et al., 2014).

Given the nutrient-rich characteristics of the Pampean streams, and considering that the salinization process in the area is related to both chronic and pulse disturbances, it was the aim of this article to study their effects on biofilms. For this purpose, we exposed the mature community to two treatments of stream water enriched with sodium chloride in microcosms and compared the results to control microcosms where no salt additions were performed. We hypothesized that the increased salinity in the stream water would produce significant changes in the biofilm, such as a) a decrease in bacterial and algal biomass, and therefore in oxygen consumption of the biofilm; b) an increase in the total carbohydrate production, as the biofilm would release additional extracellular substances to buffer the effects of the stressor; c) the modification of the community composition, as some taxa would benefit from the salinity increment while others would be impaired by it, and; d) an increased proportion of nuclear abnormalities in diatoms. We also predicted that a chronic exposure would cause a greater effect on the community than the pulse exposures, and that the biofilm would recover to control levels after a recovery period of $72 \mathrm{~h}$ when the treatments were discontinued.

\section{Materials and methods}

\subsection{Experimental design}

Glass tiles $\left(1 \mathrm{~cm}^{2}\right)$ with a frosted side were colonized in a nutrientrich stream that runs through the Pampean plain in Argentina ("del Gato" stream, $34^{\circ} 58^{\prime} 51.82^{\prime \prime} \mathrm{S} 58^{\circ} 3^{\prime} 11.24^{\prime \prime} \mathrm{W}$ ) for 25 days. Mean water conductivity during the colonization period was measured every 5 days at 10 am in the site, and remained between $305 \pm 9 \mu \mathrm{cm}^{-1}$. Colonized substrates were transported to the laboratory in portable fridges at $4{ }^{\circ} \mathrm{C}$, and placed in 9 glass $1.5 \mathrm{~L}$ microcosms $(24 \mathrm{~cm}$ long, $14 \mathrm{~cm}$ wide, $7 \mathrm{~cm}$ high) filled with filtered water ( $28 \mu \mathrm{m}$ pore size) from the same stream, which was recirculated by means of water pumps (Chosen PH2024 6 W).

The experimental period lasted $72 \mathrm{~h}$ : three microcosms were kept as controls with no sodium chloride additions; another three microcosms were exposed to a press-type increment in salinity (labeled "PRESS" treatment), by adding $\mathrm{NaCl}$ to the stream water $\left(24.6 \mathrm{~g} \mathrm{~L}^{-1}\right)$ to achieve a constant value of $1500 \mu \mathrm{cm}^{-1}$; and the final three microcosms were exposed to three pulse-type increments in salinity (labeled "PULSE" treatment), by adding $\mathrm{NaCl}$ to the stream water $\left(24.6 \mathrm{~g} \mathrm{~L}^{-1}\right)$ to raise conductivity to $1500 \mu \mathrm{Scm}^{-1}$ for 30 min every $24 \mathrm{~h}$. After each pulse addition achieved in the PULSE treatment, water from all microcosms, including the controls, was renewed with filtered stream water. After the experimental period, water of all microcosms was renewed with stream water and no further additions of salt were performed. Filtered stream water was recirculated for an additional $72 \mathrm{~h}$ to measure the potential recovery of the community.

Sodium chloride was chosen over other salts since these watercourses are characterized by a sodium chloride type water (Carol and Kruse, 2012), and the target conductivity increase was chosen to match the mean values measured in heavily urbanized streams of the area (Gómez, 1999). Flow velocity in all experimental units was kept at $0.0035 \mathrm{~m} \mathrm{seg}^{-1}$, and temperature was kept constant at $25^{\circ} \mathrm{C}$. The light was provided by 5050 red LED lights with an intensity of $120 \mu \mathrm{mol} \mathrm{m} \mathrm{m}^{-2} \mathrm{~s}^{-1}$ of photosynthetically active radiation with a photoperiod of $14 \mathrm{~h}$ light-10 h dark.

\subsection{Variables measured}

Conductivity $\left(\mu \mathrm{Cm}^{-1}\right)$, dissolved Oxygen (DO, $\mathrm{mg} \mathrm{L}^{-1}$ ), temperature $\left({ }^{\circ} \mathrm{C}\right)$, and $\mathrm{pH}$ were measured using a Consort ${ }^{\mathrm{TM}} \mathrm{C} 933$ sensor every 6 hs. Samples for the biological parameters were collected at times 24 , 48 and $72 \mathrm{~h}$ in the experimental period and after $144 \mathrm{~h}$ in the recovery period. Three subsamples were collected from each microcosm replicate. Soluble Reactive Phosphorous (SRP, $\mathrm{mg} \mathrm{L}^{-1}$ ), Dissolved Inorganic Nitrogen (DIN, mg L ${ }^{-1}$ ), Biochemical Oxygen Demand $\left(\mathrm{BOD}_{5}, \mathrm{mg} \mathrm{L}^{-1}\right.$ ) and Chemical Oxygen Demand (COD, $\mathrm{mg} \mathrm{L}^{-1}$ ) were measured by standard methods (APHA, 1998). DIN was calculated as the sum of nitrate, nitrite, and ammonium.

For the analysis of bacterial density, chlorophyll " $a$ ", algal community composition and total carbohydrates, biofilms were separated from the glass substrate using an ultrasonic bath (three 2-minute pulses, Cleanson CS-1106 sonicator). For the analysis of nuclear abnormalities in diatoms, biofilms were separated by scraping the glass' surface with a razorblade (Barbour et al., 1999), to avoid using an ultrasonic method that could modify the cells internal components (Eriksson, 2008).

\subsubsection{Bacterial density}

Samples were stored in sterile glass vials with formalin $2 \% \mathrm{v} / \mathrm{v}$. Bacterial samples were diluted (1:100 to 1:400) and stained for $10 \mathrm{~min}$ with DAPI (4', 6-diamidino-2-phenyilindole) to a final concentration of $1 \mu \mathrm{g} \mathrm{mL}^{-1}$ (Porter and Feig, 1980), and filtered through a $0.2 \mu \mathrm{m}$ black polycarbonate filter (GE Osmonics). Bacteria were then counted using an epifluorescence microscope (Olympus BX-50) under $1000 \times$ 
magnification and with an Olympus Q-Color5 imaging system. Twenty fields were counted for a total of 400 to 800 organisms per replicate.

\subsubsection{Chlorophyll-a}

Chlorophyll- $a$ content was measured by spectrophotometric methods. Sonicated samples were filtered through Sartorious GF/C filters. Chlorophyll- $a$ was then extracted with $90 \%$ acetone for $12 \mathrm{~h}$. The supernatant was read in a UV-VIS Auto 2602 spectrophotometer, and the concentration was calculated according to Strickland and Parsons (1968).

\subsubsection{Oxygen consumption}

The "additional consumption method" (Knöpp, 1968; Schwoerbel, 2016) uses a substrate (peptone or glucose) to stimulate bacterial growth in the samples, assuming that if the bacterial activity is normal, the respiration associated with the reduction of the additional substrate leads to an increased oxygen consumption. This is measured as a greater oxygen depletion at the end of an incubation period. If bacteria are being inhibited by a stressor, oxygen consumption ceases or lowers significantly, therefore providing a fast and comparative measurement of the overall bacterial respiratory activity. Samples were incubated for $24 \mathrm{~h}$ after a peptone ( $40 \mathrm{mg} \mathrm{L}^{-1}$ ) spike was added, and the dissolved oxygen concentration was compared to control samples to measure consumption.

\subsubsection{Total carbohydrates}

Samples were incubated for $30 \mathrm{~min}$ in $0.5 \mathrm{~mL}$ of $5 \%$ phenol and $2.5 \mathrm{~mL}$ of concentrated $\mathrm{H}_{2} \mathrm{SO}_{4}(12 \mathrm{M})$. After allowing the tubes to cool down for $30 \mathrm{~min}$ the samples were read in a UV-VIS Auto 2602 spectrophotometer at $485 \mathrm{~nm}$ (based on Dubois et al., 1956). Total carbohydrate $\left(\mu \mathrm{g} \mathrm{cm}^{-2}\right)$ values were obtained using a glucose calibration curve.

\subsubsection{Community composition}

The densities of higher taxa of consumers (nematods, rotifers, ciliates and oligochates) and of producers (chlorophytes, euglenophytes, cyanobacteria and diatoms) in the microbenthic community (size $<1 \mathrm{~mm}$ ) were estimated using a Sedgwick-Rafter chamber in an optical microscope (Olympus BX 50) at $400 \times$ (APHA, 1998).

A detailed analysis was conducted of the diatom assemblage. Samples were cleaned with $\mathrm{H}_{2} \mathrm{O}_{2}$, washed thoroughly using distilled water and mounted on microscope slides with Naphrax®. Four hundred valves per sample were identified to the species level, according to standard floras by Patrick and Reimer (1966, 1975), Krammer and Lange-Bertalot (1986, 1988, 1991a, 1991b), Lange-Bertalot (1993, 2005), Krammer, 1992, 2000, Lange-Bertalot and Moser (1994), and Rumrich et al., 2000; the nomenclature of diatoms was updated following Spaulding et al., 2010. Shannon's diversity index (Shannon and Weaver, 1949), Pielou's evenness (Pielou, 1975) and species richness were calculated. Also, additional samples were collected from the stream at the end of the colonization period of the glass substrates, to examine the initial composition of the assemblage.

\subsubsection{Nuclear alterations in diatoms}

Samples from each microcosm were collected to assess the frequency of nuclear anomalies. For observation of the nuclei by microscopy the diatoms were stained with $2 \%$ (v/v) Hoechst 33,342 (CAS No. 23491-523 , Sigma Chemical Co.) solution, constituting $2 \mathrm{~g} \mathrm{~L}^{-1}$. Nuclear alterations were counted under $600 \times$ magnification with an epifluorescence microscope (Olympus BX50; U-MWU2, Ex. filter BP 330-385; Em. filter BA 420; dicromatic filter DM 400). A total of at least 1000 cells for each replicate were counted to determine the frequency of any one of the following nuclear alterations: abnormal nuclear location, fragmentation of the nucleus into multiple parts, and morphologic changes of the nucleus - i.e., a spreading out of the DNA caused by nuclearmembrane breakage (Debenest et al., 2008). For this evaluation, we first considered the different nuclear locations resulting from normal movements during the cell cycle, as reported by Round et al. (2007) for different diatoms, in order to establish whether or not the positions of the nuclei observed were abnormal.

\subsection{Statistical analyses}

Variations in the physical-chemical and biological variables were examined by two-way repeated measures analysis of variance (RMANOVA). The sampling times were used as the within-subjects factor (4 levels: $24 \mathrm{~h}, 48 \mathrm{~h}, 72 \mathrm{~h}$ and recovery) and the treatment was used as the between-subjects factor (3 levels: Control, Press, Pulse). Values were first transformed to $\log (\mathrm{x}+1)$ to ensure normality, which was previously assessed by the Shapiro-Wilk test (Shapiro and Wilk, 1965); homogeneity of variance was tested by using Cochran's C test (Cochran, 1951). For each variable, three subsamples from each microcosm were collected, and their mean value was used for the statistical

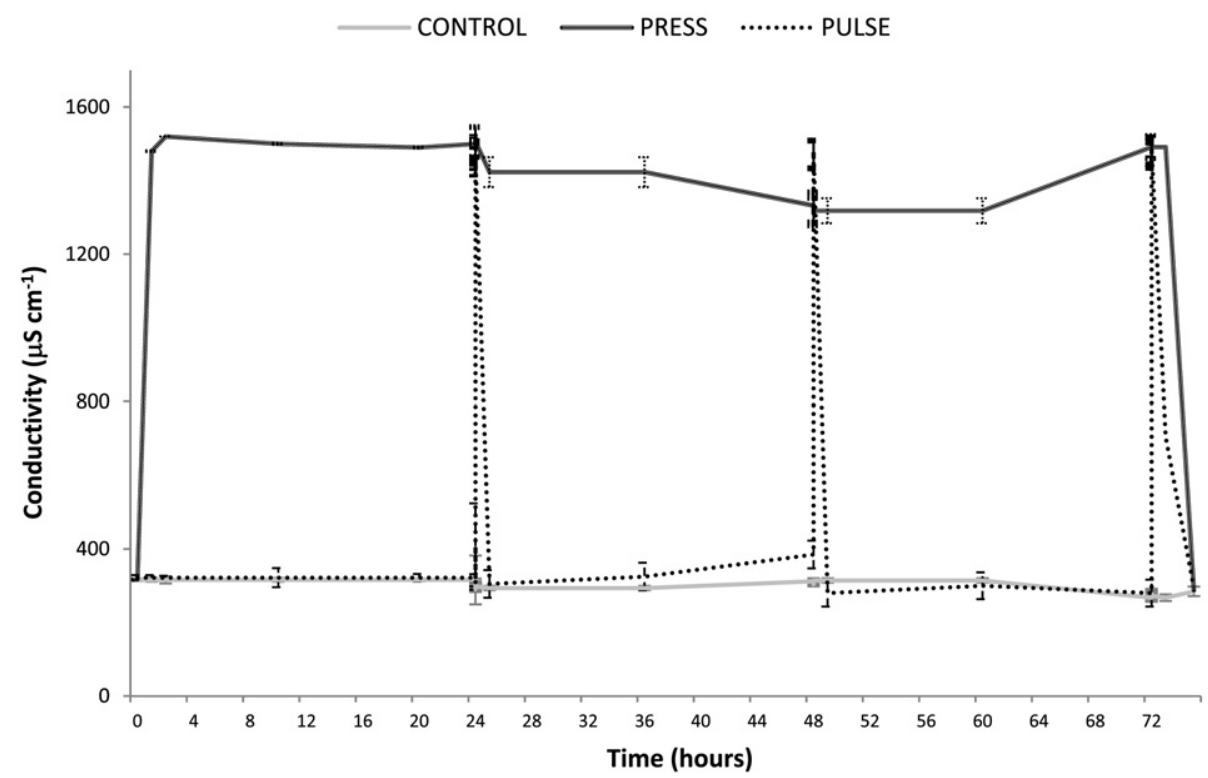

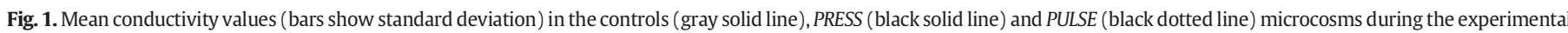
period. 
analyses. The $p$-values were corrected for false discovery rates (FDR $<0.05$, Benjamini and Hochberg, 1995), and the StudentNewman-Keuls (SNK) posthoc test was used to test for multiple comparisons. Partial eta ${ }^{2}\left(\eta^{2}\right)$ was computed as a measure of the effect size, and pairwise comparisons were conducted to establish if any significant effects of the treatments were present per date.

The overall differences between the controls and treatments in the species composition were analyzed conducting an Analysis of Similarity (ANOSIM). The indicator species of diatoms in each treatment group were identified using IndVal analysis (Dufrene and Legendre, 1997). This analysis assigns each taxon to a most probable group (Control, Press, Pulse) based on its relative abundances and relative frequencies in each group; it provides an indicator value and tests for the statistical significance of the associations by Monte Carlo permutations ( $\mathrm{n}=$ 1000).

\section{Results}

\subsection{Physical-chemical variables}

Temperature, dissolved oxygen and $\mathrm{pH}$ values were similar among treatments and dates throughout the experimental and recovery periods (Two-way RM-ANOVA, $\mathrm{p}>0.05$ ). In all microcosms, the temperature was kept between 23.7 and $26.4{ }^{\circ} \mathrm{C}$; DO values ranged from 7.4 to $10.3 \mathrm{mg} \mathrm{L}^{-1}$; and $\mathrm{pH}$ between 8.2 and 8.9 . Variations in conductivity during the $72 \mathrm{~h}$ of the experiment are shown in Fig. 1. During the recovery period, the conductivity values in all microcosms were similar $\left(288 \pm 4.72 \mu \mathrm{S} \mathrm{cm}^{-1}\right)$.

There were also no significant differences in nutrient concentrations between dates or treatments (Two-way RM-ANOVA, $\mathrm{p}<0.05$ ). SRP values ranged from 0.61 to $1.35 \mathrm{mg} \mathrm{L}^{-1}$, DIN ranged from 0.03 to $0.6 \mathrm{mg} \mathrm{L}^{-1}$, BOD 5 between 5 and $31 \mathrm{mg} \mathrm{L}^{-1}$, and COD between 13 and $76 \mathrm{mg} \mathrm{L}^{-1}$.

\subsection{Bacterial density}

Mean and standard deviation values for the biological variables measured are shown in Fig. 2. The bacterial density diminished in both the PULSE and PRESS treatments after $48 \mathrm{~h}$ of exposure $\left(\mathrm{p}<0.05, \mu^{2}=\right.$ 0.927 ), and recovered to levels similar to the controls after the recovery period.

\subsection{Community respiration, chlorophyll-a and carbohydrates}

The oxygen consumption decreased due to the PRESS treatment after $24 \mathrm{~h}$ of exposure $(\mathrm{p}<0.05)$, recovering to control levels after the recovery period. In the microcosms exposed to the PULSE treatment, this variable decreased after $48 \mathrm{~h}$ of exposure $(\mathrm{p}<0.05$ ) (Fig. 2, Table 1$)$. No significant differences were found between treatments or dates concerning either chlorophyll- $a$ concentrations or total carbohydrates in the sediment (Table 1).

\subsection{Nuclear abnormalities in diatoms}

The percentage of nuclear abnormalities in diatoms underwent a significant increase $(\mathrm{p}<0.05)$ in the PRESS treatment after 48 and $72 \mathrm{~h}$ of exposure (Fig. 3, Table 1 ). After the recovery period this percentage decreased but was still significantly higher than the one measured at both the control and PULSE treatments. Cells with broken nuclear membrane contributed the most to the total nuclear alterations (Fig. 3).

\subsection{Community composition}

The analysis of higher taxa of the biofilm showed that the most abundant groups among producers were chlorophytes and diatoms, among consumers the ciliates prevailed (Supplementary material,
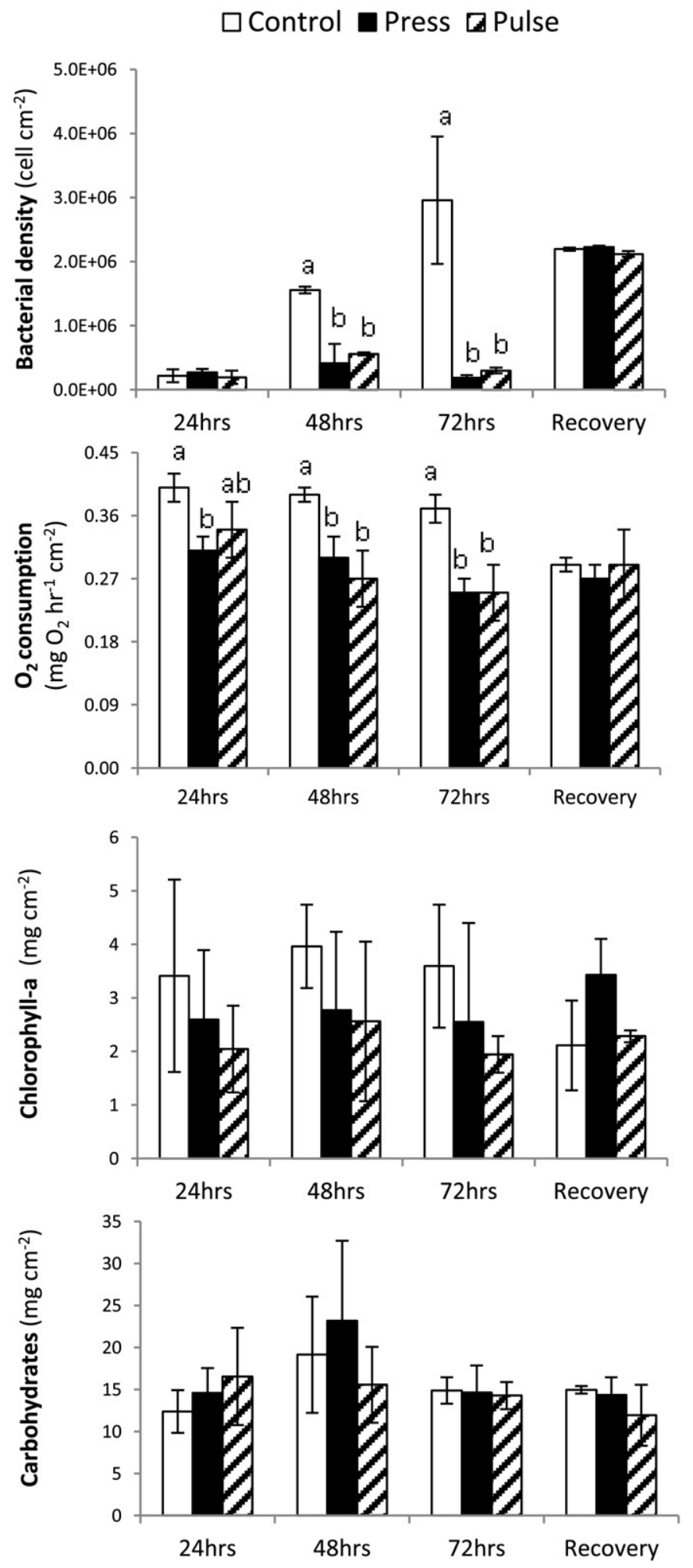

Fig. 2. Mean and standard deviations (whiskers) of $\mathrm{O}_{2}$ consumption, bacterial density, chlorophyll- $a$ and carbohydrates, in the controls and the two treatments (PRESS and PULSE) during the experimental period (24, 48 and $72 \mathrm{~h}$ ) and after the recovery period (Recovery). In those dates where significant differences were found, the letters $\left({ }^{*} \mathrm{a},{ }^{*} \mathrm{~b},{ }^{*} \mathrm{ab}\right)$ indicate the groupings resulting from the a posteriori test.

Table 1), and their densities were not significantly altered by the treatments (Table 1).

The diatom flora of the mature biofilm collected in field prior to the experiment (Fig. 4) was dominated by Diadesmis confervacea (30\%), Nitzschia amphibia (20\%), and Gomphonema parvulum, G. clavatum, 
Table 1

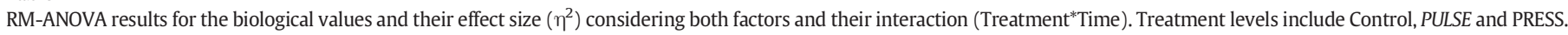

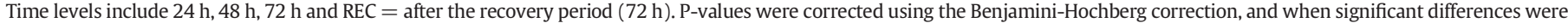
found $\left({ }^{*}=\mathrm{p}<0.05\right)$, the a posteriori test results are shown.

\begin{tabular}{|c|c|c|c|c|}
\hline Variable & & Treatment & Time & Treatment*Time \\
\hline \multirow{2}{*}{$\mathrm{O}_{2}$ Consumption $\mathrm{mg} \mathrm{cm}^{-2} \mathrm{~h}^{-1}$} & $\mathrm{p}$ & $\mathbf{0 . 0 0 2}^{*}$ PRESS $>$ PULSE $=$ Control & $\mathbf{0 . 0 2 7}^{*} 24>48=72=$ Recovery & 0.244 \\
\hline & $\eta^{2}$ & 0.958 & 0.699 & 0.467 \\
\hline \multirow[t]{2}{*}{ Bacterial density cells $\mathrm{cm}^{-2}$} & $\mathrm{p}$ & $\mathbf{0 . 0 4 0}^{*}$ Control $>$ PULSE $=$ PRESS & 0.100 & 0.100 \\
\hline & $\eta^{2}$ & 0.927 & 0.811 & 0.422 \\
\hline \multirow{2}{*}{ Clorophyll-a mg cm${ }^{-2}$} & $\mathrm{p}$ & 0.800 & 0.149 & 0.780 \\
\hline & $\eta^{2}$ & 0.107 & 0.390 & 0.156 \\
\hline \multirow[t]{2}{*}{ Carbohydrates $\mu \mathrm{g} \mathrm{cm}^{-2}$} & $\mathrm{p}$ & 0.289 & 0.698 & 0.477 \\
\hline & $\eta^{2}$ & 0.467 & 0.090 & 0.306 \\
\hline \multirow[t]{2}{*}{ Diatom abundance ind. $\mathrm{cm}^{-2}$} & $\mathrm{p}$ & 0.292 & 0.725 & 0.954 \\
\hline & $\eta^{2}$ & 0.189 & 0.080 & 0.061 \\
\hline \multirow[t]{2}{*}{ Total nuclear alterations \% } & $\mathrm{p}$ & $0^{027}{ }^{*}$ PRESS $>$ PULSE $=$ Control & $\mathbf{0 . 0 1 4}^{*} 24=$ Recovery $<48=72$ & 0.317 \\
\hline & $\eta^{2}$ & 0.885 & 0.608 & 0.411 \\
\hline Species richness & $\mathrm{p}$ & 0.160 & 0.089 & 0.923 \\
\hline No of species & $\eta^{2}$ & 0.572 & 0.784 & 0.088 \\
\hline \multirow{2}{*}{ Species diversity bits ind ${ }^{-1}$} & $\mathrm{p}$ & 0.386 & 0.138 & 0.822 \\
\hline & $\eta^{2}$ & 0.363 & 0.704 & 0.126 \\
\hline Species evenness & $\mathrm{p}$ & 0.477 & 0.149 & 0.804 \\
\hline \multirow{2}{*}{ Clorophytes ind. $\mathrm{cm}^{-2}$} & $\mathrm{p}$ & 0.948 & 0.555 & 0.720 \\
\hline & $\eta^{2}$ & 0.015 & 0.082 & 0.132 \\
\hline \multirow[t]{2}{*}{ Euglenophytes ind. $\mathrm{cm}^{-2}$} & $\mathrm{p}$ & 0.496 & 0.155 & 0.135 \\
\hline & $\eta^{2}$ & 0.093 & 0.193 & 0.314 \\
\hline \multirow[t]{2}{*}{ Cyanobacteria ind. $\mathrm{cm}^{-2}$} & $\mathrm{p}$ & 0.511 & 0.543 & 0.400 \\
\hline & $\eta^{2}$ & 0.090 & 0.084 & 0.213 \\
\hline \multirow[t]{2}{*}{ Ciliates ind. $\mathrm{cm}^{-2}$} & $\mathrm{p}$ & 0.116 & 0.257 & 0.555 \\
\hline & $\eta^{2}$ & 0.214 & 0.152 & 0.173 \\
\hline \multirow[t]{2}{*}{ Rotifers ind. $\mathrm{cm}^{-2}$} & $\mathrm{p}$ & 0.326 & 0.362 & 0.872 \\
\hline & $\eta^{2}$ & 0.132 & 0.123 & 0.091 \\
\hline \multirow[t]{2}{*}{ Nematods ind. $\mathrm{cm}^{-2}$} & $\mathrm{p}$ & 0.514 & 0.342 & 0.802 \\
\hline & $\eta^{2}$ & 0.089 & 0.128 & 0.111 \\
\hline \multirow[t]{2}{*}{ Other groups ind. $\mathrm{cm}^{-2}$} & $\mathrm{p}$ & 0.901 & 0.300 & 0.300 \\
\hline & $\eta^{2}$ & 0.023 & 0.139 & 0.139 \\
\hline
\end{tabular}

Nitzschia palea and Halamphora veneta as subdominant species. In the control and treatments samples from the microcosms a total of 153 species of diatoms were identified (those with a relative abundance $>1.5 \%$ in at least one sample are shown in Supplementary material, Table 2), but only six were dominant or subdominant species in the samples reaching $60-95 \%$ of relative abundance (Table 2). No significant differences were found in the relative abundances of the species of diatoms between controls and treatments (ANOSIM $\mathrm{p}=0.41$ ), in species' richness, diversity or evenness in the diatom assemblage (RM-ANOVA, $\mathrm{p}>0.05)$.

\section{- Nuclear fragmentation $\mathbf{\nabla}$ Abnormal location $\square$ Membrane breakage}

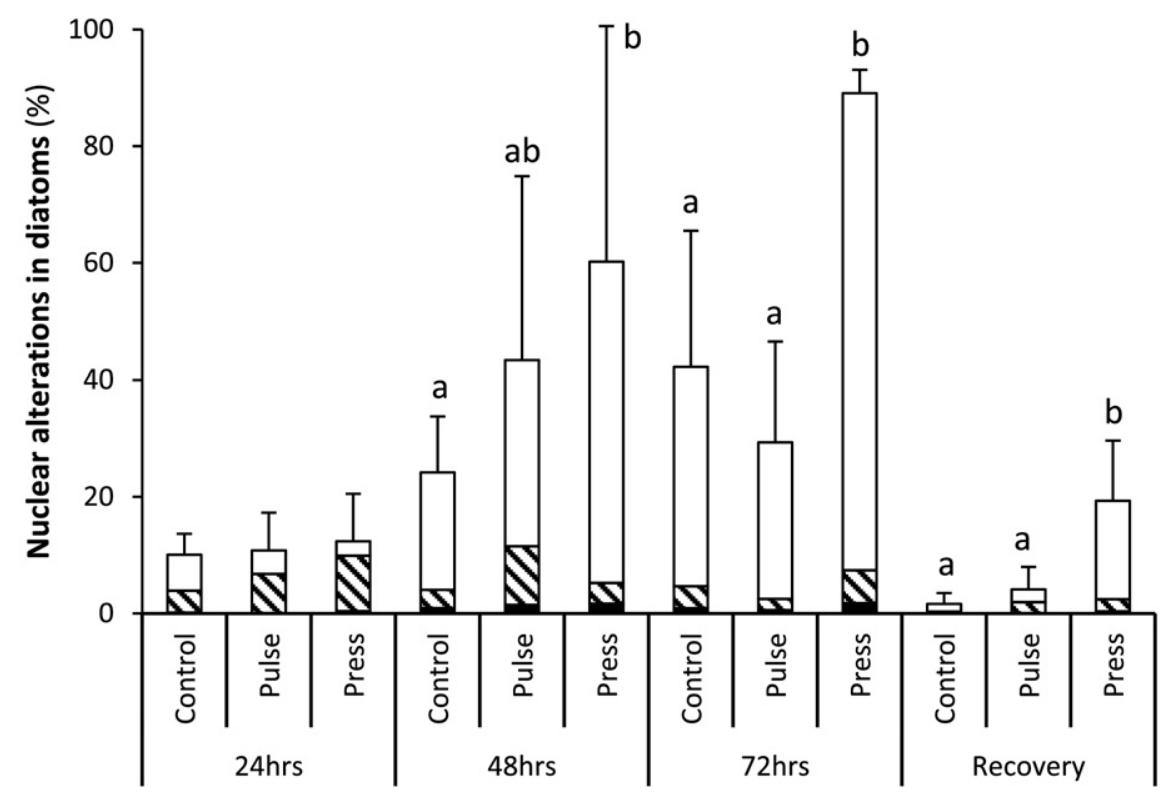

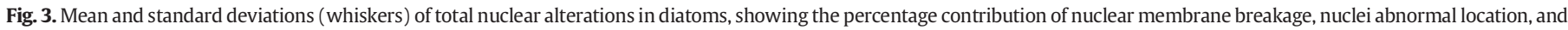

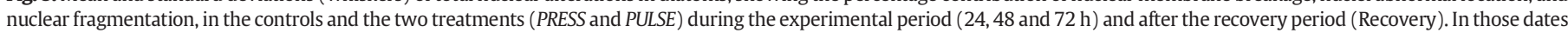
where significant differences were found in the total alterations, letters ( $\left.{ }^{*} \mathrm{a},{ }^{*} \mathrm{~b},{ }^{*} \mathrm{ab}\right)$ indicate the groupings resulting from the $a$ posteriori test. 


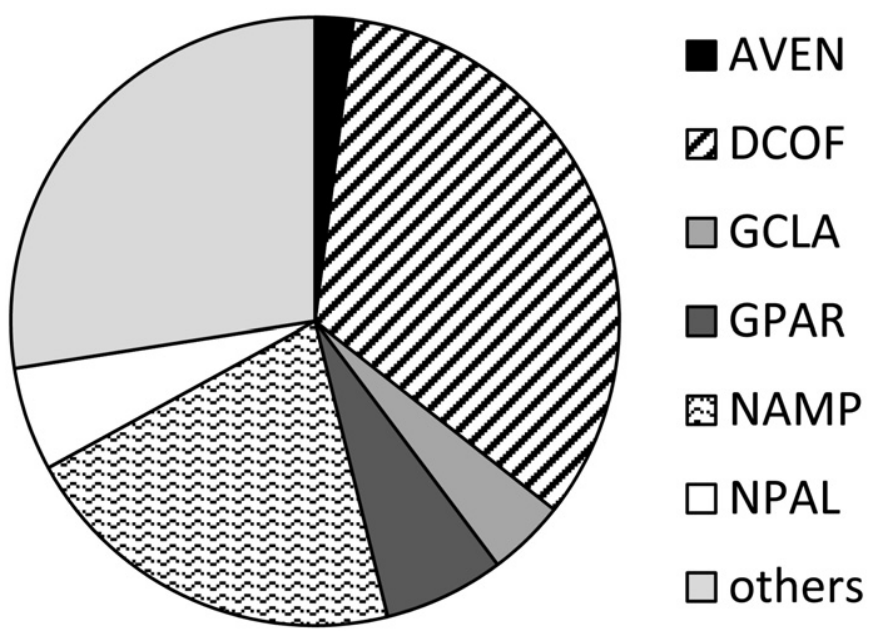

Fig. 4. Relative abundance of the main species of diatoms in the fluvial biofilms prior to the experiment. AVEN: Halamphora veneta, DCOF: Diadesmis confervacea, GCLA: Gomphonema clavatum, GPAR: Gomphonema parvulum, NAMP: Nitzschia amphibia, NPAL: Nitzschia palea, others $=$ rest of the species.

According to the IndVal analysis, eight indicator species were identified (Table 3). Indicator species within the PRESS treatment were Navicula veneta, Encyonema silesiacum, Sellaphora seminulum, Halamphora montana, Nitzschia dissipata var.dissipata and Surirella tenera. Indicator species within the PULSE treatment included Craticula subminuscula and Nitzschia amphibia.

\section{Discussion}

After a short exposure to both pulse and press additions of salt, the responses in the biofilm did not entirely match our initial hypotheses, although some changes were significant. A decrease in the bacterial density was evident in both treatments, also related to a reduction in oxygen consumption. Reductions in bacterial density and respiration by up to $20-50 \%$ were previously reported (Wichern et al., 2006) immediately following a salt addition to different types of humid soil, and
Table 3

Results of the IndVal analysis for the treatments (PRESS, PULSE) showing the indicator species $(p<0.05)$, their indicator value and their frequency in the samples.

\begin{tabular}{lllll}
\hline Species & Treatment & Ind. value & $\mathrm{p}$ & Frequency \\
\hline Navicula veneta & PRESS & 51.1 & 0.013 & 30 \\
Encyonema silesiacum & PRESS & 51.1 & 0.008 & 29 \\
Sellaphora seminulum & PRESS & 45.6 & 0.026 & 17 \\
Amphora montana & PRESS & 42.5 & 0.035 & 15 \\
Nitzschia dissipata var.dissipata & PRESS & 30.7 & 0.037 & 5 \\
Surirella tenera & PRESS & 27.3 & 0.048 & 3 \\
Eolimna subminuscula & PULSE & 46.5 & 0.041 & 19 \\
Nitzschia amphibia & PULSE & 40.1 & 0.039 & 33 \\
\hline
\end{tabular}

could be explained by the osmotic shock that the bacteria are exposed to when salt is added, which can lead to cell death (Hart et al., 1991).

Additionally, the chronic treatment in particular caused a significantly higher proportion of abnormal nuclei in the diatom assemblage, particularly due to the breakage of the nuclear membrane. The knowledge of the effects of $\mathrm{NaCl}$ on the diatom cellular nucleus is scarce, although there are multiple reports of nuclear alterations in those algae as a consequence of exposures to aldehydes, herbicides, colchicine, ultraviolet radiation, or heavy metals (Buma et al., 1995, 1996; Rijstenbil, 2001; Casotti et al., 2005; Debenest et al., 2008, 2010; Desai et al., 2006; Licursi and Gómez, 2013). Previous research in animal cells has shown that nuclear breaks caused by high $\mathrm{NaCl}$ are not quickly repaired, and they persist as long as $\mathrm{NaCl}$ remains high and accumulates over time (Dmitrieva et al., 2003), which is consistent with the results obtained in our study within the diatom assemblage.

Previous research has found that chronic disturbances produced a more severe impact on ecosystem functioning than pulse disturbances, thereby highlighting the role of persistence when attempting to predict disturbance effects on an ecosystem (Gutiérrez-Cánovas et al., 2012). In terms of algal biomass, the chlorophyll- $a$ concentration has been reported to be affected by salinity, and intermediate magnitudes in chronic exposures enhanced the development of the algal biomass, but with negative effects at higher salinity levels (Silva et al., 2000; Ros et al., 2009; Rotter et al., 2013). On the other hand, several pulse additions of salt had no effects in the chlorophyll- $a$ concentration (Cañedo-

Table 2

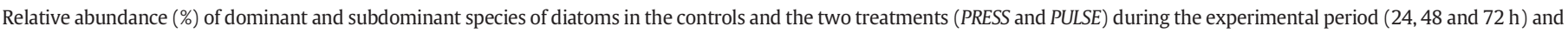

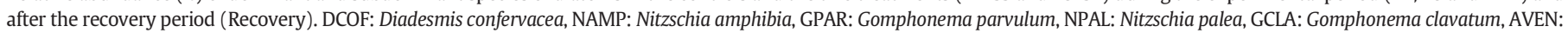
Halamphora veneta.

\begin{tabular}{|c|c|c|c|c|c|c|c|}
\hline Treatment & Time & DCOF & NAMP & GPAR & NPAL & GCLA & AVEN \\
\hline CONTROL & 24 & $\begin{array}{l}38.0 \\
( \pm 30.3)\end{array}$ & $\begin{array}{l}15.3 \\
( \pm 4.0)\end{array}$ & $\begin{array}{l}8.7 \\
( \pm 5.8)\end{array}$ & $\begin{array}{l}4.4 \\
( \pm 4.1)\end{array}$ & $\begin{array}{l}4.7 \\
( \pm 3.1)\end{array}$ & $\begin{array}{l}2.2 \\
( \pm 1.7)\end{array}$ \\
\hline PRESS & 24 & $\begin{array}{l}54.4 \\
( \pm 20.8)\end{array}$ & $\begin{array}{l}15.8 \\
( \pm 7.6)\end{array}$ & $\begin{array}{l}2.9 \\
( \pm 0.3)\end{array}$ & $\begin{array}{l}4.2 \\
( \pm 3.2)\end{array}$ & $\begin{array}{l}2.8 \\
( \pm 0.3)\end{array}$ & $\begin{array}{l}1.3 \\
( \pm 1.0)\end{array}$ \\
\hline PULSE & 24 & $\begin{array}{l}55.4 \\
( \pm 12.9)\end{array}$ & $\begin{array}{l}16.8 \\
( \pm 6.0)\end{array}$ & $\begin{array}{l}2.7 \\
( \pm 1.2)\end{array}$ & $\begin{array}{l}5.2 \\
( \pm 3.2)\end{array}$ & $\begin{array}{l}2.8 \\
( \pm 1.5)\end{array}$ & $\begin{array}{l}1.9 \\
( \pm 1.7)\end{array}$ \\
\hline CONTROL & 48 & $\begin{array}{l}58.9 \\
( \pm 13.6)\end{array}$ & $\begin{array}{l}11.6 \\
( \pm 4.5)\end{array}$ & $\begin{array}{l}2.1 \\
( \pm 2.5)\end{array}$ & $\begin{array}{l}4.9 \\
( \pm 5.4)\end{array}$ & $\begin{array}{l}5.4 \\
( \pm 1.7)\end{array}$ & $\begin{array}{l}2.4 \\
( \pm 0.8)\end{array}$ \\
\hline PRESS & 48 & $\begin{array}{l}47.7 \\
( \pm 1.9)\end{array}$ & $\begin{array}{l}19.5 \\
( \pm 2.5)\end{array}$ & $\begin{array}{l}4.3 \\
( \pm 0.1)\end{array}$ & $\begin{array}{l}2.7 \\
( \pm 0.6)\end{array}$ & $\begin{array}{l}5.9 \\
( \pm 1.2)\end{array}$ & $\begin{array}{l}1.6 \\
( \pm 0.9)\end{array}$ \\
\hline PULSE & 48 & $\begin{array}{l}51.9 \\
( \pm 5.9)\end{array}$ & $\begin{array}{l}20.6 \\
( \pm 9.7)\end{array}$ & $\begin{array}{l}2.6 \\
( \pm 2.4)\end{array}$ & $\begin{array}{l}3.5 \\
( \pm 3.1)\end{array}$ & $\begin{array}{l}3.8 \\
( \pm 0.9)\end{array}$ & $\begin{array}{l}1.4 \\
( \pm 0.9)\end{array}$ \\
\hline CONTROL & 72 & $\begin{array}{l}40.5 \\
( \pm 21.2)\end{array}$ & $\begin{array}{l}16.2 \\
( \pm 4.9)\end{array}$ & $\begin{array}{l}6.4 \\
( \pm 1.7)\end{array}$ & $\begin{array}{l}4.7 \\
( \pm 5.0)\end{array}$ & $\begin{array}{l}2.4 \\
( \pm 2.4)\end{array}$ & $\begin{array}{l}2.5 \\
( \pm 0.5)\end{array}$ \\
\hline PRESS & 72 & $\begin{array}{l}39.9 \\
( \pm 18.6)\end{array}$ & $\begin{array}{l}13.2 \\
( \pm 1.9)\end{array}$ & $\begin{array}{l}6.9 \\
( \pm 3.9)\end{array}$ & $\begin{array}{l}5.3 \\
( \pm 2.8)\end{array}$ & $\begin{array}{l}5.2 \\
( \pm 2.8)\end{array}$ & $\begin{array}{l}3.0 \\
( \pm 1.3)\end{array}$ \\
\hline PULSE & 72 & $\begin{array}{l}46.7 \\
( \pm 11.5)\end{array}$ & $\begin{array}{l}17.0 \\
( \pm 3.8)\end{array}$ & $\begin{array}{l}5.2 \\
( \pm 1.4)\end{array}$ & $\begin{array}{l}4.4 \\
( \pm 3.1)\end{array}$ & $\begin{array}{l}4.4 \\
( \pm 1.3)\end{array}$ & $\begin{array}{l}1.4 \\
( \pm 0.1)\end{array}$ \\
\hline CONTROL & Recovery & $\begin{array}{l}75.6 \\
( \pm 11.8)\end{array}$ & $\begin{array}{l}8.7 \\
( \pm 0.3)\end{array}$ & $\begin{array}{l}0.9 \\
( \pm 0.6)\end{array}$ & $\begin{array}{l}1.5 \\
( \pm 1.8)\end{array}$ & $\begin{array}{l}3.1 \\
( \pm 2.6)\end{array}$ & $\begin{array}{l}1.5 \\
( \pm 0.7)\end{array}$ \\
\hline PRESS & Recovery & $\begin{array}{l}54.2 \\
( \pm 11.3)\end{array}$ & $\begin{array}{l}16.3 \\
( \pm 0.9)\end{array}$ & $\begin{array}{l}5.9 \\
( \pm 2.3)\end{array}$ & $\begin{array}{l}1.0 \\
( \pm 0.5)\end{array}$ & $\begin{array}{l}4.3 \\
( \pm 2.9)\end{array}$ & $\begin{array}{l}2.6 \\
( \pm 2.1)\end{array}$ \\
\hline PULSE & Recovery & $\begin{array}{l}57.5 \\
( \pm 6.0)\end{array}$ & $\begin{array}{l}18.7 \\
( \pm 7.4)\end{array}$ & $\begin{array}{l}4.4 \\
( \pm 0.4)\end{array}$ & $\begin{array}{l}0.6 \\
( \pm 0.5)\end{array}$ & $\begin{array}{l}3.9 \\
( \pm 0.4)\end{array}$ & $\begin{array}{l}0.9 \\
( \pm 0.9)\end{array}$ \\
\hline
\end{tabular}


Argüelles et al., 2014). In our study, neither pulse nor chronic treatments increased the algal biomass, although longer exposure times might be needed for this structural change to occur.

There were also no clear effects on the densities of producers (chlorophytes, euglenophytes, cyanobacteria) or consumers (rotifers, ciliates, nematods). Even the composition, diversity and evenness of the diatom assemblage were not altered significantly, despite that it is well known that diatoms can react to rather small changes in salinity (Zimmermann-Timm, 2007; Trobajo et al., 2011; Rovira et al., 2012). This could be related to the fact that the diatom assemblage during the colonization period was composed by salt-tolerant species, such as Diadesmis confervacea, Nitzschia amphibia and Nitzschia palea, reported as freshwater-brackishwater species by Van Dam et al. (1994), and with ecological tolerances for the Pampean streams ranging from 348 to $2505 \mu \mathrm{S} \mathrm{cm}^{-1}$ (Licursi et al., 2010). Cañedo-Argüelles et al. (2014) also did not record significant differences in the composition of the diatom assemblage due to the salinity pulses, and suggested that the dominance by salt tolerant species (Amphora indistincta, Cocconeis pediculus and Cocconeis placentula) may explain the diffuse effects of salinization on the diatom assemblage. The eight indicator species found in our results also consist of freshwater-brackishwater species (Van Dam et al., 1994; Licursi et al., 2010), most of them related to the chronic treatment, although their indicator value was too low to consider them good salinity indicators (IndVal $<55 \%$ ).

We had also hypothesized an increase in the total carbohydrate concentration, since the release of extracellular polymeric substances has been shown to increase as a response to a salinity stress (Decho, 2000; Steele et al., 2014). However this variable did not change significantly throughout the experiment, although the extraction procedure used does not allow measuring any possible variations in the different fractions of the matrix (colloidal extracellular polysaccharides, low molecular weight carbohydrates, proteins, etc.).

Previous research conducted on biofilms of Pampean streams have indicated that they are usually well adapted to tolerate moderate changes in the water quality (Artigas et al., 2013; Cochero et al., 2013; Licursi et al., 2016), although the recovery in the biofilm after the experimental period could be related to the short exposition time. Nevertheless, the resilience of these communities is an important aspect to be studied further, considering longer exposition times and stronger intensities of the treatments.

To conclude, both the chronic and pulse additions of salt caused significant alterations in the biofilm. Although the former usually cause permanent changes in the aquatic ecosystems (Bender et al., 1984), the pulse additions have also been proven of relevance even on higher trophic levels. For instance, the density, diversity and drift of the macroinvertebrate community were altered after only $72 \mathrm{~h}$ of exposition (Cañedo-Argüelles et al., 2012); or even the salt slug addition technique, a well established technique and widely used by stream ecologists to measure the characteristics of the stream flow, has been found to increase the drift of macroinvertebrates (Wood and Dykes, 2002). It is therefore important in future research and management plans to contemplate if the effects of short pulses of pollutants caused by specific events (e.g. irrigation, increased discharges from industries at specific hours, etc.) could have significant impacts on the biota.

\section{Acknowledgements}

This study was funded by CONICET Project PIP 296, UNLP-CONICET Project PIO 13420130100004CO, and UNLP project N736. We would like to particularly thank Lic. Mercedes Nicolosi Gelis and Lic. Santiago Tarda for their assistance in the lab, and Lic. Jorge Donadelly for the nutrient analyses. We would also like to thank the anonymous reviewers and the editor of the journal for their comments, that helped improve this manuscript substantially. The present article is scientific contribution number 999 of the Institute of Limnology “Dr. Raúl A. Ringuelet” (ILPLA, CCT-La Plata CONICET, UNLP).

\section{Appendix A. Supplementary data}

Supplementary data to this article can be found online at http://dx. doi.org/10.1016/j.scitotenv.2016.11.152.

\section{References}

Abed, R.M.M., Kohls, K., De Beer, D., 2007. Effect of salinity changes on the bacterial diversity, photosynthesis and oxygen consumption of cyanobacterial mats from an intertidal flat of the Arabian Gulf. Environ. Microbiol. 9:1384-1392. http://dx.doi.org/10. 1111/j.1462-2920.2007.01254.x.

APHA, 1998. Standard Methods for Examination of Water and Wastewater. 20th ed American Public Health Association, American Water Works Association and Water Pollution Control Federation, Washington (1325pp).

Artigas, J., García-Berthou, E., Bauer, D.E., Castro, M.I., Cochero, J., Colautti, D.C., ... Giorgi, A 2013. Erratum: global pressures, specific responses: effects of nutrient enrichment in streams from different biomes. Environ. Res. Lett. 8 (1), 9601.

Baldwin, D.S., Rees, G.N., Mitchell, A.M., Watson, G., Williams, J., 2006. The short-term effects of salinization on anaerobic nutrient cycling and microbial community structure in sediment from a freshwater wetland. Wetlands 262, 455-464.

Barbour, M.T., Gerritsen, J., Snyder, B.D., Stribling, J.B., 1999. Rapid Bioassessment Protocols for Use in Streams and Wadeable Rivers. USEPA, Washington.

Bender, E.A., Case, T.J., Gilpin, M.E., 1984. Perturbation experiments in community ecology: theory and practice. Ecology 651, 1-13.

Benjamini, Y., Hochberg, Y., 1995. Controlling the false discovery rate: a practical and powerful approach to multiple testing. J. R. Stat. Soc. Ser. B Methodol. 289-300.

Buma, A.G., Hannen, E.J., Roza, L., Veldhuis, M.J., Gieskes, W.W., 1995. Monitoring ultraviolet-b-induced DNA damage in individual diatom cells by immunofluorescent thymine dimer detection. J. Phycol. 312, 314-321.

Buma, A.G.J., Zemmelink, H.J., Sjollema, K., Gieskes, W.W.C., 1996. UVB radiation modifies protein and photosynthetic pigment content, volume and ultrastructure of marine diatoms. Mar. Ecol. Prog. Ser. 1421, 47-54.

Busse, S., Jahn, R., Schulz, C.J., 1999. Desalinization of runningwaters: II. Benthic diatom communities: a comparative field study on responses to decreasing salinities. Limnologica 29, 465-474.

Cañedo-Argüelles, M., Grantham, T.E., Perrée, I., Rieradevall, M., Céspedes-Sánchez, R., Prat, N., 2012. Response of stream invertebrates to short-term salinization: a mesocosm approach. Environ. Pollut. 166, 144-151.

Cañedo-Argüelles, M., Kefford, B.J., Piscart, C., Prat, N., Schäfer, R.B., Schulz, C.J., 2013. Salinisation of rivers: an urgent ecological issue. Environ. Pollut. 173, 157-167.

Cañedo-Argüelles, M., Bundschuh, M., Gutiérrez-Cánovas, C., Kefford, B.J., Prat, N., Trobajo R., Schäfer, R.B., 2014. Effects of repeated salt pulses on ecosystem structure and functions in a stream mesocosm. Sci. Total Environ. 476, 634-642.

Cañedo-Argüelles, M., Hawkins, C.P., Kefford, B.J., Schäfer, R.B., Dyack, B.J., Brucet, S., Buchwalter, D., Dunlop, J., Frör, O., Lazorchak, J., Coring, E., Fernandez, H.R. Goodfellow, W., González Achem, A.L., Hatfield-Dodds, S., Karimov, B.K., Mensah, P., Olson, J.R., Piscart, C., Prat, N., Ponsá, S., Schulz, C.J., Timpano, A.J., 2016. Saving freshwater from salts. Science 351 (6276), 914-916.

Carol, E.S., Kruse, E.E., 2012. Hydrochemical characterization of the water resources in the coastal environments of the outer Río de la Plata estuary, Argentina. J. S. Am. Earth Sci. 37, 113-121.

Casotti, R., Mazza, S., Brunet, C., Vantrepotte, V., Ianora, A., Miralto, A., 2005. Growth inhibition and toxicity of the diatom aldehyde 2-trans, 4-trans-decadienal on Thalassiosira weissflogii Bacillariophyceae. J. Phycol. 411, 7-20.

Cochero, J., Romaní, A.M., Gómez, N., 2013. Delayed response of microbial epipelic biofilm to nutrient addition in a Pampean stream. Aquat. Microb. Ecol. 692, 145-155.

Cochran, W.G., 1951. Testing a linear relation among variances. Biometrics 7, 17-32.

Davis, J.A., McGuire, M., Halse, S.A., Hamilton, D., Horwitz, P., McComb, A.J., Froend, R.H. Lyons, M., Sim, L., 2003. What happens when you add salt: predicting impacts of secondary salinisation on shallow aquatic ecosystems by using an alternative-states model. Aust. J. Bot. 51, 715-724.

Debenest, T., Silvestre, J., Coste, M., Delmas, F., Pinelli, E., 2008. Herbicide effects on freshwater benthic diatoms: induction of nucleus alterations and silica cell wall abnormalities. Aquat. Toxicol. 881, 88-94.

Debenest, T., Silvestre, J., Coste, M., Pinelli, E., 2010. Effects of pesticides on freshwater diatoms. In: Whitacre, D.M. (Ed.), Reviews of Environmental Contamination and Toxicology. Springer, New York, pp. 87-103.

Decho, A.W., 2000. Microbial biofilms in intertidal systems: an overview. Cont. Shelf Res. 2010, 1257-1273.

Desai, S.R., Verlecar, X.N., Goswami, U., 2006. Genotoxicity of cadmium in marine diatom Chaetoceros tenuissimus using the alkaline comet assay. Ecotoxicology 154, 359-363.

Dmitrieva, N.I., Bulavin, D.V., Burg, M.B., 2003. High NaCl causes Mre11 to leave the nucleus, disrupting DNA damage signaling and repair. Am. J. Physiol. Renal Physiol. 2852, 266-274.

Dubois, M., Gilles, K.A., Hamilton, J.K., Rebers, P.A., Smith, F., 1956. Colorimetric method for determination of sugars and related substances. Anal. Chem. 283, 350-356.

Dufrene, M., Legendre, P., 1997. Species assemblages and indicator species: the need for a flexible asymmetrical approach. Ecol. Monogr. 673, 345-366.

Eriksson, K.M., 2008. Impacts of Antifouling Compounds on Photosynthesis, Community Tolerance and psbA Genes in Marine Periphyton.

Feijoó, C.S., Lombardo, R.J., 2007. Baseline water quality and macrophyte assemblages in Pampean streams: a regional approach. Water Res. 417, 1399-1410.

Giorgi, A., Feijoó, C., Tell, G., 2005. Primary producers in a Pampean stream: temporal variation and structuring role. Biodivers. Conserv. 147, 1699-1718.

Gómez, N., 1999. Epipelic diatoms of a high contamined basin from Argentina MatanzaRiachuelo river: biotic indices and multivariate analysis. Aquat. Ecosyst. Health Manag. 2, 301-309. 
Gutiérrez-Cánovas, C., Hernández, J., Millán, A., Velasco, J., 2012. Impact of chronic and pulse dilution disturbances on metabolism and trophic structure in a saline Mediterranean stream. Hydrobiologia 6861, 225-239.

Hart, B.T., Bailey, P., Edwards, R., Hortle, K., James, K., McMahon, A., Swadling, K., 1991. A review of the salt sensitivity of the Australian freshwater biota. Hydrobiologia 2101$2,105-144$

Herbst, D.B., Blinn, D.W., 1998. Experimental mesocosm studies of salinity effects on the benthic algal community of a saline lake. J. Phycol. 34:772-778. http://dx.doi.org/ 10.1046/j.1529-8817.1998.340772.x.

Hoagland, K.D., Rosowski, J.R., Gretz, M.R., Roemer, S.C., 1993. Diatom extracellular polymeric substances: function, fine structure, chemistry, and physiology. J. Phycol. 295, 537-566.

Ivorra, N., Bremer, S., Guasch, H., Kraak, M.H., Admiraal, W., 2000. Differences in the sensitivity of benthic microalgae to $\mathrm{Zn}$ and $\mathrm{Cd}$ regarding biofilm development and exposure history. Environ. Toxicol. Chem. 195, 1332-1339.

Knöpp, H., 1968. Stoffwechseldynamische Untersuchungsverfahren für die biologische Wasseranalyse (Metabolism - dynamics tests for biological water analysis). Int Revue ges. Hydrobiol. Hydrogr. 533, 409-441.

Krammer, K., 1992. Pinnularia, eine Monographie der europäischen Taxa. Bibl. Diatomol. $26,1-353$.

Krammer, K., 2000. The genus Pinnularia. In: Lange-Bertalot, H. (Ed.), Diatoms of Europe Vol 1. A.R.G. Gantner Verlag, Ruggell (572pp).

Krammer, K., Lange-Bertalot, H., 1986. SüBwasswasserflora von Mitteleuropa, Bacillariophyceae 1, Naviculaceae. Gustav Fischer Verlag, Stuttgart (876 pp).

Krammer, K., Lange-Bertalot, H., 1988. SüBwasswasserflora von Mitteleuropa, Bacillariophyceae 2, Bacillariaceae, Epithemiaceae, Surirellaceae. Gustav Fischer Verlag, Stuttgart (596 pp).

Krammer, K., Lange-Bertalot, H., 1991a. SüBwasswasserflora von Mitteleuropa, Bacillariophyceae 3, Centrales, Fragilariaceae, Eunotiaceae. Gustav Fischer Verlag, Stuttgart (576 pp).

Krammer, K., Lange-Bertalot, H., 1991b. SüBwasswasserflora von Mitteleuropa, Bacillariophyceae 4, Achnanthaceae. Literaturverzeichnis, Gustav Fischer Verlag Stuttgart (437 pp).

Kruse, E., Laurencena, P., Varela, L., Rojo, A., Deluchi, M., 2005. Hydrological characterization of the brackish-fresh water relationship in different morphological environments of the province of Buenos Aires, Argentina. Geological Survey of Spain: Series on Hydrogeology and Groundwater. 15, pp. 305-312.

Lange-Bertalot, H., 1993. 85 New Taxa. Vol 2/1-4. J. Cramer, Berlin (453pp).

Lange-Bertalot, 2005. Diatoms of Uruguay. Iconographia Diatomologica 5. A.R.G. Gantner Verlag, K.G. (735pp).

Lange-Bertalot, H., Moser, G., 1994. Brachysira, Monographie der Gattung. J. Cramer, Berlin (211pp).

Licursi, M., Gómez, N., 2013. Short-term toxicity of hexavalent-chromium to epipsammic diatoms of a microtidal estuary Río de la Plata: responses from the individual cell to the community structure. Aquat. Toxicol. 134, 82-91.

Licursi, M., Gómez, N., Donadelli, J., 2010. Ecological optima and tolerances of coastal benthic diatoms in the freshwater-mixohaline zone of the Río de la Plata estuary. Mar. Ecol. Prog. Ser. 418, 105-117.

Licursi, M., Gómez, N., Sabater, S., 2016. Effects of nutrient enrichment on epipelic diatom assemblages in a nutrient-rich lowland stream, Pampa Region, Argentina. Hydrobiologia 7661, 135-150.

Lovett, S., Price, P., Edgar, B., 2007. Salt, Nutrient, Sediment and Interactions: Findings from the National River Contaminants Program.

Nielsen, D.L., Brock, M.A., Rees, G.N., Baldwin, D.S., 2003. Effects of increasing salinity on freshwater ecosystems in Australia. Aust. J. Bot. 516, 655-665.

Patrick, R., Reimer, C.W., 1966. The diatoms of the United States, exclusive of Alaska Hawaii, Vol. 1. Acad. Natl. Sci. Phila. 13 (1), 1-688.
Patrick, R., Reimer, C.W., 1975. The Diatoms of the United States, exclusive of Alaska Hawaii, Vol. 2, Part 1. Acad. Natl. Sci. Phila. 13 (2/1), 1-213.

Pielou, E.C., 1975. Ecology Diversity. J. Wiley and Sons, New York.

Pilkaitytë, R., Schoor, A., Schubert, H., 2004. Response of phytoplankton communities to salinity changes-a mesocosm approach. Hydrobiologia 5131-3, 27-38.

Porter, K.G. Feig Y.G. 1980. The use of DAPI for identifying and counting aquatic microflora. Limnol. Oceanogr. 41, 595-604.

Rijstenbil, J., 2001. Effects of periodic, low UVA radiation on cell characteristics and oxidative stress in the marine planktonic diatom Ditylum brightwellii. Eur. J. Phycol. 361, $1-8$.

Ros, M.D., Marín-Murcia, J.P., Aboal, M., 2009. Biodiversity of diatom assemblages in a Mediterranean semiarid stream: implications for conservation. Mar. Freshw. Res. $601,14-24$

Rotter, S., Heilmeier, H., Altenburger, R., Schmitt-Jansen, M., 2013. Multiple stressors in periphyton - comparison of observed and predicted tolerance responses to high ionic loads and herbicide exposure. J. Appl. Ecol. 50, 1459-1468.

Round, F.E., Crawford, R.M., Mann, D.G., 2007. The Diatoms: Biology Morphology of the Genera. Cambridge University Press, Cambridge, UK (747pp).

Rovira, L., Trobajo, R. Ibáñez, C., 2012. The use of diatom assemblages as ecological indicators in highly stratified estuaries and evaluation of existing diatom indices. Mar. Pollut. Bull. 64, 500-511.

Rumrich, U., Lange-Bertalot, H., Rumrich, M., 2000. Diatoms of the Andes from Venezuela to Patagonia/Tierra del Fuego. Iconographia diatomologica 9, 1-649.

Schwoerbel, J., 2016. Methods of Hydrobiology: Freshwater Biology. Elsevier (210pp).

Shannon, C.E., Weaver, W., 1949. The Mathematical Theory of Communication. University of Illinois press.

Shapiro, S.S., Wilk, M.B., 1965. An analysis of variance test for normality complete samples. Biometrika 52 (3-4), 591-611.

Silva, E.I.L., Davies, R.W., 1999. The effects of simulated irrigation induced changes in salinity on metabolism of lotic biota. Hydrobiologia 416, 193-202.

Silva, E.I.L., Shimizu, A., Matsunami, H., 2000. Salt pollution in a Japanese stream and its effects on water chemistry and epilithic algal chlorophyll-a. Hydrobiologia 4371-3, $139-148$

Spaulding, S.A., Lubinski, D.J., Potapova, M., 2010. Diatoms of the United States. http:// westerndiatoms.colorado.edu (Accessed on 27 May 2016).

Steele, D.J., Franklin, D.J., Underwood, G.J., 2014. Protection of cells from salinity stress by extracellular polymeric substances in diatom biofilms. Biofouling 308, 987-998.

Strickland, J.D.H., Parsons, T.R., 1968. A practical handbook of seawater analysis. Pigment analysis. B. J. Fish. Res. Board Can. 167, 310.

Trobajo, R., Rovira, L., Mann, D.G., Cox, E.J., 2011. Effects of salinity on growth and on valve morphology of five estuarine diatoms. Phycol. Res. 592, 83-90.

Van Dam, H., Mertens, A., Sinkeldam, J., 1994. A coded checklist and ecological indicator values of freshwater diatoms from the Netherlands. Neth. J. Aquat. Ecol. 281, $117-133$.

Wichern, J., Wichern, F., Joergensen, R.G., 2006. Impact of salinity on soil microbial communities and the decomposition of maize in acidic soils. Geoderma 1371, 100-108.

Wood, P.J., Dykes, A.P., 2002. The use of salt dilution gauging techniques: ecological considerations and insights. Water Res. 3612, 3054-3062.

Wunsam, S., Kamenik, C., Schmidt, R., 2002. Epilithic diatoms in an Alpine lake Traunsee, Austria affected by soda and salt mining industries. Water Air Soil Pollut. Focus 24, 93-108.

Zhang, L., Gao, G., Tang, X., Shao, K., 2014. Impacts of different salinities on bacterial biofilm communities in fresh water. Can. J. Microbiol. 605, 319-326.

Zimmermann-Timm, H., 2007. Salinisation of inland waters, chapter 2. Water Uses and Human Impacts on the Water Budget. Verlag Wissenschaftliche Auswertungen/ GEO, Hamburg, pp. 133-136. 